\title{
The Combination of Environmental Art Design and Regional Square Design under the Mass Media of Communication
}

\author{
Zhou Xiao \\ Architecture and Urban Planning College \\ Southwest Minzu University \\ Chengdu, China 610041
}

\begin{abstract}
In the contemporary society, the ceaseless development of scientific and technological level and the emergence of new media technology make the cultural diffusion convenient. Works of environmental art design that use new media technology emerge continuously, bringing development and innovation for the regional design of urban landscape. On the basis of urban square, this paper will analyze the development and utilization of mass media in the urban environmental art design, explaining the problems, in order to help urban designers to better conduct the landscape design by virtue of the artistic technology under new media in the future development.
\end{abstract}

Keywords-mass media; environmental art design square; regionalism

\section{INTRODUCTION}

In the design of modern urban art, designers use mass media technology to make the urban landscape smarter and more beautiful, making the buildings of the whole city take on a new look. Particularly, the acousto-optic technology and the interactive media technology intensify the influence of landscape and make people personally on the scene. Besides, it strengthens the interaction between cities and residents and reflects the harmonious development among people, society and the natural environment. Next, we will analyze the application of environmental technology in square design under the new media, to help you better understand the environmental art.

\section{ENVIRONMENTAL ART AND THE REGIONALISM OF SQUARE DESIGN}

\section{A. The Subject of Environmental Art Design Is Designers.}

The subject of environmental art is the designers with different cultural backgrounds. They come from different regions and possess different knowledge backgrounds under

Fund project: Funds for young teachers in the special fund project of basic scientific research business fee of central universities-the phased research fruits of the research project on improving the combination of artistry and regionalism of urban square in the national regions in the urbanization.

Fund No.: 2014SZYQN73 the influence of different cultural environments. Designers from different regions will show distinct aesthetic mentality in face of the same environment. When the environmental design of somewhere needs a fixed plan, contradictions emerge. The unified thinking will not form for a long time, leading to the delay even interrupt of design. The thinking of designers determines the design thought and the aesthetic practice of the masses. This is one of the reasons why the characteristic buildings of many places are designed by local designers in the whole process.

\section{B. Square Design}

The urban square is the main place for the masses the take activities. As the outdoor public space of each city, it enables citizens to take physical exercise, realize recreation and entertainment and affective interaction, so it must be pleasing to the eye. At the meantime, it still plays an important role in enriching urban landscape and organizing urban traffic. The square design is the epitome of economy and culture of a city. Square is the hub of all the urban roads and the place for people to take social activities and communication. Many important buildings surround a square, representing the cultural characteristics and artistic appearance of the city. A square is the core of a city. Although there are not too many squares in a city and it does not cover a large area, it is always the most important part of urban landscape design because of its significant role and position. An urban square comprises single large buildings as well as many buildings and surrounding regions, such as the government office center, shopping mall, commercial pedestrian streets and department stores. With the continuous development of society, besides the material life, people also pursue the satisfaction on thought and mentality. Therefore, the square design must change the original nature, inheriting and improving the original function and position and keeping up with the social development, roundly and profoundly representing the regional and cultural connotation of a city, in order to better serve the people and the city. 


\section{The Combination of Environmental Art with the Regionalism of Square Design}

The diffusion of environmental art is convenient, scientific and attractive. In the design of urban square, designers use such media arts as the design art of communication and network, digital audio and video and digital interaction, which can effectively create the atmosphere and make people personally on the scene. The environmental art becomes popular to make people more interested in it. In addition, it increases the interaction between appreciators and the environmental art, making people more intuitively enjoy the aesthetic feelings brought by the environmental art.

The Crown Fountain completed in 2004 is located in the square of Millennium Park in Chicago. The subject is the reflection pool formed by the black granite. The glass towers installing LED luminous diode with the height of 12.5 meters stand on both sides. The interior is a display screen with the height of 15 meters, with the real-time control of the computer. It conducts the loop playback of the smiling faces of 1,000 citizens in Chicago, welcoming the tourists. Moreover, from May to October in each year, fountains spray from the smiling mouths of citizens, surprising and cooling the tourists.

The application of environmental art and local regionalism in the design of urban square can expand the manifestation pattern of art design and enrich the core connotation of art design, guaranteeing the better and more modernized development of urban square.

\section{THE APPLICATION OF ENVIRONMENTAL ART IN THE SQUARE DESIGN ART}

\section{A. The Influence of Environmental Art on the Regionalism of Urban Square Design}

The environmental art innovates and improves unceasingly with the development of science and technology. It is widely applied to many fields because of its strong diffusion and easy operation, especially the urban landscape design. The development of environmental art expands the space for designers to show and enables designers to conduct the urban landscape design through more scientific and advanced artistic and technological methods. At present, the square design by virtue of the environmental art is at the preliminary exploration stage, only involving experiment and advertising. The emergence of environmental art breaks the regionalism of original urban landscape design. The application of light scribe, animated video technology and interactive technology makes appreciators and the urban square design better infuse and communicate, in order to make the urban square more useful.

The environmental art design has been widely used in the design of urban square at abroad. For example, the interactive dance projection technology is popular in many European urban squares. Tourists in the square can wobble at will or make some gestures, which will reflect on the large screen or the surrounding buildings through the shadow casting technique, in order to strengthen the interaction between people and make people more enthusiastic about getting close to the square. In Sanlitun Village of Beijing, the environmental art design is fully integrated in the square design. People at any corner of the square feel the surprise brought by the environmental design and deeply integrate in the atmosphere. The LED large screen above the Village Hall conducts the loop playback of advertising or videos to attract people. All in all, the environmental art has gradually integrated in the regional design of urban square and feasts eyes, ears and feelings of people. People can truly participate in and enjoy art in leisure and entertainment as well as shopping. On the other hand, enterprises and governments can make use of the resources brought by media arts to publicize products and themselves, in order to effectively strengthen the connection and communication of enterprise, government and the public.

\section{B. The Function of Environmental Art in the Urban Square Design}

1) Make the urban square more public and regional: Most importantly, urban squares are public and regional, providing space for the masses to relax and take public activities. The square design depending on the environmental art centers on the publicity. Different from the general art, the urban landscape art must be closer to people's life. The traditional art is high level and difficult for people to appreciate and understand. While urban landscape art breaks through the limitation and shows art in a way easier for people to accept. The works designed come from people's life and make people better appreciate and enjoy the urban landscape art.

The design of the Crown Fountain mentioned above just highlights the publicity of urban square. Using LED screen to show citizens' smiling faces can strengthen the appreciators' cordial feeling and sense of identity and make appreciators faster integrate in the square with a relaxed attitude. The design of the Fountain turns the two-dimensional space into three-dimensional, making the dull screen vivid and the square more artistic. People in any angle of the square can feel the artistry brought by the Crown Fountain. It attracts people to stop to watch even participate in it, reflecting the publicity of urban square very well.

2) Strengthen the interactivity of urban square: The contemporary urban square has been quite different from the traditional one. Instead of the place for the masses to get together and take political activities, it integrates political propaganda, cultural exchange, leisure and entertainment and shopping. The introduction of environmental art under the mass media shows the still art with dynamic forms like light scribe, LED screen and fountains, effectively strengthening the interaction between the square and the masses and their sense of participation and identity, so that they will truly integrate in the urban square.

3) Expand the road of urban square design: The traditional methods of urban landscape design are limited, which restricts designers. The emergence of environmental art under media breaks through limitation, so that designers draw on their imagination and realize the design philosophy that cannot realize originally. Furthermore, the emergence of environmental art brings inspiration for designers and 
connects things of different nature through media technology, strengthening the spatiality of design.

\section{The Application of Environmental Art in Urban Square Design}

1) Combine with the attachment concept of original art design of the urban landscape: The urban landscape design connects the square with the masses and integrates them in a popular form to promote the more harmonious development of the whole society. For example, the "Sun Valley" in the World Expo is provided for people to enjoy the cool and get together. In reality, the tensile structure can effectively collect solar energy and rainwater and apply the solar energy to the electricity generation of interior LED light band in the evening, making the "Sun Valley" more artistic and beautiful, so that people are more willing to have a rest and stroll about in the "Sun Valley".

2) Combine with the emerging concept of environmental art under media: Different from the general art, the urban landscape design is closer to people's life and public. The emergence of environmental art creates conditions for the publicity of urban landscape design and lets designers truly give play to the publicity of urban square. In the Light Festival in Sydney combines with the environmental art under mass media, the designed animation and lights are projected on the Sydney Opera House and other renowned government buildings through shadow casting technique and light scribe. The grotesque lights shorten the distance between the masses and the urban square. For the water screen film in Tang Paradise in Xi'an, the traditional films are projected on the running water through shadow casting technique. It increases the dynamic beauty of films and highlights the concept and connotation of media arts.

\section{CONCLUSION}

It has been a recognized tendency to combine the environmental art with the regional design of urban square. The environmental art can inherit the traditional concept of art and design and expand the design channel, bringing ideological basis and design conditions for designers. The urban landscape design technique at home is not so advanced. Government and designers shall conduct the art design through advanced environmental technology and break the traditional and conservative design concept. Only in this way can we give full play to the function of urban square and furthest promote more harmonious relationship between cities and people.

\section{REFERENCES}

[1] Quan Huimin, Li Yanan. The Art of Urban Square Design [J], Sculpture, 2008, 02: 62-63

[2] Mu Qing. The Application of Public Art of New Media in the Urban Commercial Plaza [J], Art Science and Technology, 2014, 05:257

[3] Ma Jun, Zhang Xinyu. Analysis on the Public Art of Contemporary Urban Square and the Crossover Design of Media Arts [J], Decoration, 2012, 03:139-140

[4] Chen Xiaojie. View Analysis and Visual Language Recombination in the Modern Urban Square [D], Tsinghua University, 2004
[5] Ouyang Yongfeng. Research on the Humanization Design of Urban Square [D], Northwest Agriculture and Forestry University, 2005 